\title{
A Defence of Contemporary Economics: Zombie Economics in Review
}

\author{
Stephen D. Williamson
}

\section{Introduction}

John Quiggin wants what fundamentally all economists want. He would like to make society better off. Of course, economists differ over how that goal should be accomplished. Quiggin thinks that society would be better off if income and wealth were redistributed from the currently rich to the currently poor, if there were a larger role for the government, and if fluctuations in aggregate employment were mitigated or eliminated entirely.

But Quiggin is dissatisfied. There are obstacles which impede progress. In particular, according to Quiggin, there are some widely accepted ideas in contemporary economics that are obviously wrong, yet economists and policymakers cling to those ideas. The solution to Quiggin's problem is that we kill the offending ideas — zombie ideas - and in Zombie Economics: How Dead Ideas Still Walk Among Us (Quiggin 2010) he also proposes how we should fill the void.

Quiggin frames his thinking in terms of five zombie ideas:

1. The Great Moderation

2. The Efficient Markets Hypothesis

3. Dynamic Stochastic General Equilibrium (DSGE)

4. Trickle-down Economics

5. Privatization.

In Zombie Economics, a chapter is devoted to each zombie idea. The idea is laid out - its intellectual origins, and the basic outlines of how the idea has been used in economics. Then, Quiggin makes the case for why the idea is a zombie idea. A genuine zombie idea must be clearly useless; indeed, Quiggin sometimes wants to make the stronger case that the idea is actually dangerous. Further, the zombie walks; that is, economists and others cling to the bad idea in spite of 
strong evidence that reveals the zombie idea to be silly. Much of the evidence Quiggin has in mind relates to the recent financial crisis. Finally, he offers some proposals for how the perceived deficit in ideas can be remedied.

Thus, Zombie Economics is not only a critique of a set of economic ideas; it is a condemnation of economic science as a whole. If economics were a healthy science, then economists would be skilled at separating the wheat from the chaff - embracing good ideas, throwing out bad ideas, and developing and expanding on the good ones.

Is Zombie Economics a good book? Our assessment must depend on how the standard is set. In this case we should expect a lot. Quiggin is an economist with a recognised record of peer-reviewed published work, and has received prestigious awards, including recognition as a Distinguished Fellow of the Economic Society of Australia and Fellow of the Econometric Society. Unfortunately, Zombie Economics is a big letdown. Parts of it are poorly written and confusing, if not self-contradictory. Sometimes the zombie ideas themselves are not clearly elucidated, so that it is hard to understand whether Quiggin is obfuscating or just confused; Quiggin is not always clear on where the zombie ideas go wrong; and his solutions are typically vague, misguided, or are not new.

What follows is my critique of Quiggin's critique. I will provide my own take on contemporary economics, what it contributes and where I think it can be improved, along with some discussion of aspects of the financial crisis and how it should shape our thinking.

\section{The Great Moderation}

\section{Self-congratulation}

The Great Moderation is typically taken to be the time period in the United States following the 'Volcker recession' in the early 1980s, until the most recent recession - a period characterized by low inflation, by low variability in inflation, and by low variability in real GDP about trend.

In Zombie Economics, Quiggin seems to want to question whether that characterization is correct, but the Great Moderation is indeed a fact; its rough characterization is something that is obvious to the naked eye from aggregate time series, with any reasonable filtering of the data.

Now, of course we should be suspicious of anyone who argues that we have observed a discrete and permanent change in macroeconomic performance, and 
sometimes the pronouncements of such people look silly in retrospect. One of the people that appears to look silly in the wake of the financial crisis is Ben Bernanke, who spoke as a Federal Reserve Governor in 2004 (Bernanke 2004) on the Great Moderation and its causes.

Bernanke argued that the Great Moderation could be attributed significantly to good policy, good luck, and to structural change in the economy. In particular, he thought that the Fed could claim a good part of the credit for the good macroeconomic performance of the previous 20-plus years. Bernanke did not state outright that the Great Moderation represented a permanent change in the operating characteristics of the US economy, but certainly his discussion of the role of monetary policy and structural change seemed to indicate that he thought those developments were permanent. Bernanke did not say that a financial crisis could not happen, but perhaps we can fault him for not having discussed the possibility. Did the possibility of a financial crisis not enter his mind at the time? Did he think of a financial crisis as a piece of bad luck that the Fed could deal with after the fact, using standard tools? Of course we cannot read Bernanke's former mind, so who knows?

Is the notion that the Great Moderation represented a permanent change in macroeconomic performance a zombie idea? Recall that a genuine zombie idea must be widely held, it must be wrong, and the idea must persist in light of clear evidence that it is wrong. To answer the question, it helps to think in terms of Bernanke's three contributing factors: policy, luck, and structural change.

On the question of the policy contribution, macroeconomists were somewhat divided at the time Bernanke made his speech. There was wide agreement that the Volcker/Greenspan period represented a marked change in inflation control by the Fed, for the better. However, the sizeable fraction of macroeconomists who were sceptical about the Fed's ability to influence the behaviour of real GDP were inclined to attribute the low volatility in real GDP during the Great Moderation to good luck and/or structural change rather than to monetary policy. ${ }^{1}$

On structural change, it is not a new idea that an economy open to international trade in goods and assets might experience more volatility, or that deregulation might be a two-edged sword. For example, the Deregulation and Monetary Control Act (MCA) of 1980 removed Regulation Q, a well-known source of aggregate volatility in the United States. Prior to 1980, a 'disintermediation' phenomenon occurred, whereby an increase in nominal interest rates would cause a withdrawal of funds from accounts in savings and loan institutions (S\&Ls) subject to interest rate ceilings. Much of those withdrawals would typically find

1 There is a literature in which vector autoregression approaches are used to account for the causes of the Great Moderation. See Stock and Watson (2002), and the references cited in that paper. 
their way into money-market mutual funds, with the result being a contraction of mortgage market credit. The MCA eliminated Regulation Q, thus curing the disintermediation problem, but the Act also deregulated S\&Ls, making them more like commercial banks. The downside of the MCA was that the regulators of S\&Ls did a poor job of correcting the moral hazard problem associated with deposit insurance among the newly deregulated S\&Ls. The result was a wave of S\&L failures, beginning in the late 1980s, and a massive federal government bailout of S\&L depositors - a financial crisis, as it were.

So, we might say that the notion of a permanent change in macroeconomic performance was widely held, with some qualifications. But Quiggin is incorrect in stating that this view persists today, whether he can find a quote to support that view or not. I do not see many economists convinced that the United States will ever return to the trend growth path of about three per cent real GDP growth per year to which it adhered fairly closely after World War II, let alone a vociferous group willing to make forecasts about the long-run volatility of real GDP. On the future path of inflation, the forecasts are all over the map. Old Keynesians, including Paul Krugman, worry about inflation being too low. Old Monetarists, and some recent dissenters on the Federal Open Market Committee (the decision-making arm of the Fed) are concerned that policy mistakes could make the inflation rate much too high.

\section{Keynesianism, new and old}

So, there does not appear to be a genuine zombie idea associated with the Great Moderation. But does Quiggin have anything useful to say about the related issues? Well, not really. Quiggin views the period after World War II until 1970 as a 'Golden Age of Keynesianism [that] delivered big increases in living standards throughout the developed world.'2

So, why does Quiggin not address the fact that in the United States, the pre1970 growth path does not look so different from the post-1970 growth path (leaving out the recent financial crisis and recession)? The answer is that this does not conveniently fit into his narrative. As becomes clearer later in Zombie Economics, Quiggin likes Old Keynesian economics (though he wants some changes) but he is not a big fan of post-1970 macroeconomic thought, nor of New Keynesian economics.

The key ideas in New Keynesian economics are laid out in Woodford (2003) and Clarida, Gali and Gertler (1999). New Keynesians built on post-1970 developments in macroeconomics to come up with a modern representation of Keynesian ideas that they intended for use by practical-minded central bankers.

2 See Quiggin (2010): 28. 
The approach, like the 'neoclassical synthesis' of the 1960s that attempted to integrate the ideas of Old Monetarists and Old Keynesians, was put forward as a framework which would satisfy Keynesian critics while also articulating a role for activist policy.

There was a problem though. On the one hand, New Keynesians were speaking to the Keynesian critics of the 1970s and 1980s and telling them that they had a point. On the other hand, the message that Old Keynesians were getting from the New Keynesians was that they should not worry. The New Keynesians would look after the troublesome critics, and Old Keynesians should feel free to stay on course. New Keynesianism in reduced form (Clarida, Gali and Gertler 1999) looks much like Old Keynesianism. There is an IS curve, and there is a Phillips curve. The LM curve disappears, to be replaced by a Taylor rule, but otherwise the language is Old Keynes, and any Old Keynesian would feel at home with it.

Since1970, monetary policy in the United States has been driven more by the Old Keynesian neoclassical synthesis than by any other paradigm. Thus, while Quiggin may like to lay blame for the complacency of the Great Moderation period on new paradigms, and attribute any success in dealing with and understanding the financial crisis to Old Keynesianism, he cannot have it both ways. Bernanke's complacency was an Old Keynesian complacency. Further, Quiggin may think that 'the end of the Great Moderation has forced policymakers to relearn the basic lessons of Keynesian economics', ${ }^{3}$ but Old Keynesian economics has little or nothing to say about financial intermediation, incentive problems, moral hazard, too-big-to-fail, and aggregate risk-bearing, which lie at the heart of the financial crisis and the ensuing recession.

\section{The Efficient Markets Hypothesis}

This chapter in Zombie Economics seems the most confused, or confusing, depending on how one looks at it. In an attempt to simplify matters in the mind of the reader, Quiggin has gathered a number of ideas under the efficientmarkets umbrella that do not belong there, thus sacrificing clarity. However, Quiggin may in fact be confused himself about what the efficient-markets hypothesis entails, or he may have conflated some different ideas intentionally, in an effort to hoodwink us. In any case, this chapter should not be your source of information if you want to learn what financial economists mean by 'efficient markets hypothesis'.

In finance, the theory of asset pricing is typically couched in partial equilibrium terms. Prices are determined by arbitrage, as, for example, in a Black-Sholes

3 See Quiggin (2010): 33. 
option pricing model, where the stochastic process for the price of the underlying stock is treated as given, and then a pricing formula is derived for the price of an option written on that stock. The efficient markets hypothesis, as the practitioners of finance see it, simply comprises the testable implications of arbitrage. To derive these arbitrage relationships we need optimisation and equilibrium. Rational financial market participants have some objective function(s), they optimise, and in equilibrium they exhaust all available profit opportunities.

In Lucas's asset-pricing model (Lucas 1978), which is well-known to economists and often referred to as the intertemporal capital asset-pricing model (ICAPM) by finance theorists, we obtain a more general type of asset-pricing relationship. Lucas's notion of asset pricing is very useful as it links asset prices to aggregate risk and the role of assets in smoothing the consumption of individuals over time. In Lucas's framework, assets are more desirable if they have big payoffs in states of the world when aggregate consumption is low, as those assets are very useful in smoothing consumption. Then, the terms on which an individual consumer is willing to hold an asset - the asset's expected return - is determined by the covariance of the asset with the consumer's intertemporal marginal rate of substitution. There is an equation determining the price of an individual asset - essentially an intertemporal arbitrage condition - the logic of which can be transferred to a wide range of general equilibrium applications.

Economists have notions of efficiency, of course, which are quite different from arbitrage-pricing efficiency. The standard such notion is Pareto efficiency, which is known - or should be known - to every economics undergraduate. Typically, when an economist speaks of 'efficiency', he or she means an allocation of resources to productive activities, and of produced goods and services to individuals that cannot be Pareto-dominated; that is, which has the property that there is no other allocation that will make everyone no worse off, while making at least one person better off. Thus, Pareto efficiency and arbitrage pricing (the 'efficient markets hypothesis') are quite different concepts.

Here is where the confusion starts. Quiggin first gives us this definition (p.35):

The Efficient Markets Hypothesis says that financial markets are the best possible guide to the value of economic assets and therefore to decisions about investment and production. This requires not only that financial markets make the most efficient possible use of information, but that they are sufficiently well-developed to encompass all economically relevant sources of risk.

This is not helpful: it is not that the 'market' guides us about the 'value' of the asset. The price of the asset is determined by how the market participants value 
it. How they come up with that valuation is the interesting part. The second sentence in the quote requires some work to interpret. By 'encompassing all economically relevant sources of risk' I think Quiggin means that standard arbitrage pricing requires the ability to perfectly diversify risk, which is indeed true. The risk that gets priced in standard asset-pricing theory is nondiversifiable risk. For example, in Lucas (1978), the non-diversifiable risk is associated with the variability in aggregate consumption. However, it is not difficult to extend basic asset-pricing ideas in models where there are frictions that prevent economic agents from diversifying perfectly.

In the above quote, Quiggin's crime is just bad writing, but the offences in the following (p. 42) are more serious: 'The Efficient Markets Hypothesis provides a case against public investment in infrastructure and implies that macroeconomic imbalances, such as trade and current account deficits, should not be regarded with concern and, provided they arise from private sector financial transactions, are actually both beneficial and desirable.'

First, Quiggin is conflating the implications of arbitrage from the efficient markets hypothesis with Pareto efficiency. But these implications are consistent with Pareto inefficiency. Arbitrage pricing can explain asset prices in the context of the standard deficiencies in the private sector that economists use to determine the appropriate role for the government - externalities, informational advantages for the government vs. the private sector, and so on. In some analyses we may uncover a relationship between a failure of some standard arbitrage-pricing theory to match the data, and an inherent advantage of the government over the private sector, but it is easy to write down counterexamples to show that arbitrage asset pricing does not rule out a role for the government.

Second, the question of whether a current account deficit (or a deficit on trade in goods and services), in itself, represents a problem is a Pareto efficiency issue and is not fundamentally an issue related to arbitrage asset pricing. It certainly is true that we get some important insights from basic frictionless models in which countries trade with each other, and the equilibrium outcome is Pareto efficient. In such an environment, countries borrow and lend on world capital markets, and if a country is running a current account deficit it is doing it for a sound reason - that country is smoothing the consumption of its residents over time and investing to grow in an efficient way. That is useful to know: we need not think of a current account deficit as a bad thing.

But public policy discussions are laced with talk of imbalances, as if a world with countries running current account deficits and surpluses is in fact bad. What are those people getting at? To think about that, we need to depart from the frictionless world and consider the consequences of debt obligations and the possibility of default. For an individual country, running an unsustainable 
current-account deficit may be a bad thing. The deficit may have arisen because of a large government budget deficit, with the government borrowing abroad to finance its spending. The deficit may in fact be unsustainable, and at the point where foreign lenders decide that is the case, the price of the country's sovereign debt drops and the country is driven into default. That is certainly not a good result, as it impairs the country's ability to smooth consumption, invest by borrowing abroad, and so on. That is, the things we know from the basic frictionless models are a key function of borrowing on foreign markets.

Does the departure from the frictionless model require that we throw out what we learned about arbitrage pricing? Not at all. While we are now in a world where some financial claims - debt obligations - are non-contingent, the same principles apply. We can still think about financial market participants who optimize and eliminate the profits from arbitrage. However, there may be a limited set of financial markets on which these participants can trade, or private information may put additional constraints on what participants can do.

\section{Asset price bubbles}

Quiggin moves on to a discussion of asset price bubbles, something we hear about a lot in discussions of the run-up to the financial crisis in the United States. One popular view is that the rapid increase in the price of real estate in the US, ending in 2006, was a kind of mania, or phenomenon of irrationality, and Quiggin appears to share that view. That might seem to be at odds with arbitrage pricing, in which the world is populated by rational individuals eliminating profit opportunities.

In my view, irrationality is the great cop-out, and simply represents a failure of imagination. Rationality is so weak a requirement that the set of potential explanations for a particular phenomenon that incorporate rationality is boundless. If the phenomenon can be described, and we can find some regularity in it, then it can also be described as the outcome of rational behaviour. Behaviour looks random only when one does not have a theory to make sense of it, and explaining it as the result of rational behaviour is literally what we mean by 'making sense of what we are seeing'. If we are accustomed to observing people who do not have schizophrenia, we might describe a schizophrenic as 'irrational', but for a trained psychiatrist, a schizophrenic behaves in predictable ways. The schizophrenic has his or her own rationality, and hard work by scientists in the field of psychiatry has taught us how to intervene in the lives of people with this mental illness to make them better off.

What do we know that can make sense of the 'bubble' in the price of real estate in the US, say over the period 2000-2006? First we need a definition for 'bubble.' To get at this, define an asset's fundamental price as what standard 
arbitrage pricing would deliver - that is, the fundamental price is the expected discounted valued of the future payoffs associated with the asset, using the appropriate discount factors from the model environment we are dealing with. Then, a bubble exists if the actual price of the asset exceeds its fundamental price. Now, monetary economists know a great deal about this kind of bubble. Valued fiat money is a bubble. The fundamental price of fiat money is zero it has no intrinsic payoffs - but the price of money is positive in terms of goods and services. Another way to think about the 'money bubble' is that the difference between the price of money and its fundamental represents a liquidity premium; that is, the value of money in exchange.

We can expand on this idea to think about assets that have intrinsic payoffs. Consider mortgage-backed securities (MBS), for example. The underlying payoffs come from payments made by mortgage-holders to the institutions that are servicing the mortgage loan contracts. Those payoffs are then dispersed in complicated ways that are determined by how the MBS was constructed. But the MBS is more than just a vehicle for diversifying the riskiness in those individual payoffs, as the MBS is also a tradeable security used in financial exchange. Indeed, before the financial crisis (as is well known) even MBS with potentially very risky underlying individual payment streams were perceived as safe assets.

Now, where would a real estate bubble come from? MBS were used extensively in financial-market asset trading prior to the financial crisis, and small quantities of MBS could potentially support a huge amount of financial exchange, as one MBS can potentially be used many times as collateral, through the process of rehypothecation (see Gorton 2010). Since MBS had value in exchange, there was an MBS bubble, and this fed back into the market in mortgage originations. Because the MBS sold at a high price reflecting their high liquidity premium, competing mortgage originators were willing to grant good terms on mortgage loans, many borrowers could finance real estate purchases who would not otherwise be able to do so, and prices of real estate shot up. Of course, the underlying mortgages, particularly in the subprime market, did not generate the promised payoffs, there were a series of fatal incentive problems in the chain of financial transactions that created some MBS, and the MBS ultimately were no longer perceived as safe, liquid assets. A huge quantity of financial exchange went away, and the bubble 'burst,' so to speak.

Now, nowhere in my story did I invoke irrationality, nor did I violate any basic principle of arbitrage pricing, though certainly there are frictions that play a key role in the story. Asset bubbles, as monetary economists understand them (see Williamson and Wright 2010, 2011) arise because of information frictions - limitations on recordkeeping and information flows. As well, the 
basic financial market incentive problems associated with the financial crisis were moral hazard and adverse selection, which are the key private information frictions that economists know a lot about.

Quiggin (p.67) draws some policy conclusions about bubbles: 'If a real estate bubble is under way, for example, central banks must have the power and willingness to direct bank lending away from the overheated sectors without unnecessarily constraining productive investment.'

As should be clear to the perceptive reader, a real estate bubble could potentially be a good thing. The reason the bubble that developed in the US over the period 2000-2006 was a bad thing was not because it was a bubble, per se, but because the bubble was built on false pretences. We should not be directing central banks to kill all the bubbles they see.

\section{Financial regulation and narrow banking}

Finally, in this chapter Quiggin addresses some issues associated with financial regulation, and comes out in favour of 'narrow banking' proposals. This raises some interesting issues. One of Quiggin's themes has to do with the destruction he sees as the result of a move toward 'market liberalism' in the world, beginning in about 1970. However, Milton Friedman, perhaps the most prominent proponent of market liberalism of all time, was actually also a key proponent of narrow banking (see Friedman 1960). Friedman proposed separating the transactions activity of banks from their portfolio activities by requiring that transactions accounts be backed one-for-one with reserve balances; that is, he argued for a 100 per cent-reserve requirement. Friedman argued that this would provide financial stability, and he used Old Monetarist principles to support his argument.

Contrary to Friedman, most monetary economists tend to think of the 100 per cent-reserve requirement as wrongheaded. Friedman neglected the important role of banks as financial intermediaries which channel savings from the holders of transactions accounts to ultimate borrowers. Thus 'separating money from credit' can generate clear inefficiencies (see, for example, Sargent and Wallace 1982).

Contemporary proposals for narrow banking — coming, for example, from Paul Volcker or Gorton and Metrick (2010) - are different from what Friedman had in mind, but share some of the same motivation, and the same problems. We can design a regulatory structure that narrowly defines particular kinds of financial intermediation activities, with the regulators then charged with the job of making sure that the financial industry stays within these particular confines. 
However, private financial intermediaries are very clever at finding ways of undoing restrictions like this, as recent history illustrates, for example in the case of the development of 'shadow banking'.

The alternative to narrow banking, of course, is broad banking, which is roughly the Canadian approach, whereby entry is restricted into the financial intermediation industry, which is dominated by a few big players. Those big players are permitted to engage in a wide range of intermediation activities, but are closely supervised by a regulator that has broad discretion to prevent financial intermediaries from engaging in practices that are deemed too risky. The Canadian approach has certainly been successful in generating stability. Since the beginning of the twentieth century there have been three chartered bank failures in Canada: there were none in the Great Depression, and the Canadian banking system emerged virtually unscathed from the recent financial crisis.

Of course, we can debate whether the Canadian approach sacrifices innovation for stability. However, the key point is that narrow banking is by no means a clear solution to perceived financial instability.

\section{Dynamic Stochastic General Equilibrium}

\section{Microfoundations, optimization, and commitment}

The watershed in modern macroeconomics came with two publications, which were the 'Phelps volume' (Phelps 1970) and Lucas (1972). It is useful at this point to extract the key ideas that evolved in the ensuing research program.

The first key idea in modern macro is that 'microeconomic foundations' are important - so important, in fact, that calling these 'foundations,' or making the distinction between what is micro and what is macro, misses the point. The economic theory used in modern macroeconomics is an integrated whole: this is not the cement that was poured to form the foundation; it comprises the walls, the floors, and the roof, along with the plumbing and electrical work. The force of the approach removes the distinction between macroeconomics and microeconomics; economic methods comprise a single set of tools, and the differences in research programs pertain only to the particular problems addressed.

Why use the available economic theory to address macroeconomic (aggregative) problems? One reason is pure efficiency. Economic theorists have put a considerable amount of thought and hard effort into developing general 
equilibrium theory, information economics, mechanism design, and the theory of contracts, for example. It would be silly for macroeconomists to turn down the gifts theorists have given us, and to go about reinventing wheels.

A second reason is one emphasised repeatedly by macroeconomists, and here the macroeconomists have something to teach some (but by no means all) microeconomists. The Lucas critique (Lucas 1976), for which we can find roots in the earlier work of the Cowles Foundation, is an argument for the use of structural models in the evaluation of macroeconomic policies. By 'structural' we mean that the features of the model are invariant with respect to any change in government policy that we are contemplating. This idea can be applied to the analysis of any type of policy change (for example, the effects of a change in the minimum wage), but in macroeconomics the potential problems produced from an astructural approach are all the more damning. In particular, due to the forward-looking behaviour of firms and consumers in a dynamic economy, the behaviour of different individuals and activity in seemingly separated markets is intertwined in complex ways. To sort out this complexity, we need to be specific about the basic building blocks of our model economy: preferences, endowments, technology, information structure, and equilibrium concept.

A second key principle in the post-1970 macroeconomic research program is adherence to optimisation - a key organising principle in all of economics. We should not base macroeconomic policy on the idea that the government can systematically fool people or can convince people to do something they might later regret. Consumers and firms do the best they can with the information they have available. That information may be quite bad, and if this seems important to the question at hand, then we should model it. Again, economic theorists have given us some useful tools for dealing with behaviour under private information, and we should use those tools when appropriate.

Finally, the ability of government policymakers to commit, and the design of mechanisms to produce commitment, is a critical element of modern dynamic macroeconomics, as first argued by Kydland and Prescott (1977). Later development of the idea (for example, Chari and Kehoe 1990) used the theory of dynamic games to help specify a game between a policymaker and the private sector. In this game, the inability of a benevolent policymaker to commit could lead to a bad outcome, but good behaviour could sometimes be supported in an equilibrium in which the loss to the policymaker of a good reputation is simply too much to bear.

What does Quiggin think of all this work? Not much, apparently. He has particular disdain for the Dynamic Stochastic Equilibrium (DSGE) Approach, by which he means the set of competitive equilibrium models developed by 
Kydland and Prescott (1982), building on the established neoclassical growth framework, and later extended by New Keynesian economists (such as Woodford 2003) to incorporate Keynesian elements.

What is it that Quiggin does not like? He comes up with some items on the usual list of complaints, for which there are standard defences. (i) We can observe economic agents behaving irrationally, so what is all this rational agent stuff about? Answer: If you think you are observing irrational behaviour, you just have the wrong model. Think harder. (ii) In the world, there is more than one economic agent; what kind of stupid model would start with a representative agent? Answer: Indeed, that is a starting point, and it is a very instructive one. We understand some basic ideas, and we also see what is missing, so we can proceed to expand the model on dimensions where we find it lacking. Almost no contemporary macroeconomic models actually conform to the representative agent paradigm; where they do, that is because it is a useful abstraction in the context of the problem addressed.

Here is a particular prescription for macroeconomic model-building that Quiggin puts forward (p.105): 'In many ways the way of doing this [building a good macro model] would be to incorporate ad hoc descriptions of aggregate relationships that fitted observed outcomes, even if it could not be related directly to individual optimization.'

What can we say? Go back and read Lucas (1976), John Quiggin. The Phillips curve is indeed an ad hoc description of an aggregate relationship fitted to observed outcomes. Samuelson and Solow, two well-respected economists whose contributions were later rewarded with Nobel prizes, proposed (Samuelson and Solow 1960) that policymakers treat that ad hoc description as a policy menu. That prescription went haywire in a big way, for reasons that have some general implications, as of course Lucas (1976) pointed out.

As relates to the financial crisis, Quiggin has this to say: 'The obvious criterion of success or failure for a macroeconomic theoretical framework is that it should provide the basis for predicting, understanding, and responding to macroeconomic crises. If that criterion is applied to the current crisis, the DSGE approach to macroeconomics has been a near total failure.'

But prediction need not always be the criterion for success of an economic model. Clearly, if we are judging a forecasting model, we want it to predict well, in some well-defined sense. But in other cases forecasting is not the name of the game. In arbitrage pricing, under some assumptions the model implies that changes in asset prices cannot be successfully forecast. By the criterion of prediction, 
the model is indeed a total failure. It tells you that a monkey could do as well at predicting asset prices as an economist who understands the model. Yet the model is actually not a failure, as it teaches us something interesting.

With financial crises, a similar issue arises. By its nature, a financial crisis is an unpredictable event. We could have an excellent model of a financial crisis. The people living in the model world where the financial crisis can happen know it can happen, but they can't predict it, otherwise they could profit in advance from that prediction. Similarly, an economist armed with the model will not be able to predict a crisis in the real world. A nice example is in Ennis and Keister (2010), which is a variant of a Diamond-Dybvig (1983) banking model. In Ennis and Keister's world, a rational and benevolent policymaker and a set of rational consumers live in an environment where a banking panic can happen. When the policymaker sees the beginnings of a panic, he or she starts to intervene, but rationally discounts the severity of the panic until the panic is too full-blown to actually prevent. Thus, the panic can happen even if the policymaker has the right model, and the policymaker with the right model indeed cannot predict the panic.

Next, arguing that standard DSGE models are not useful in understanding crises is a bit of a cheap shot. The basic real business-cycle model (see Prescott 1986, for example) was not designed for the purpose of understanding financial crises, but for understanding some of the basics of business-cycle phenomena. Granted, if regular financial crises are deemed an important feature of business cycles, then it would certainly be useful for a business-cycle model to include such phenomena. That does not mean Prescott (1986) is not useful, or not instructive. That paper is included on many reading lists in graduate programs in economics for good reasons - and not because it is some 'zombie' that macroeconomists refuse to kill. The basic real business-cycle model gives the student an insight into dynamic optimisation in a general equilibrium context, intertemporal substitution, and allows us to consider the possibility that business cycles might indeed be phenomena we simply need to tolerate.

\section{Where do we look for improvements?}

Though it is silly to dismiss post-1970 macroeconomics as a waste of time, it is certainly reasonable to take New Keynesians to task for neglecting financial and monetary factors in their models (see Williamson and Wright 2010). Such models were designed specifically to be used in guiding monetary policy, but were not very useful in providing prescriptions for dealing with the financial crisis, since they left out the details of credit market activity, monetary and asset exchange, and financial intermediation. In fact, one would think such features would be at the heart of what a central banker should be concerned with, financial crisis or 
not. However, that need not cause us to deem all of post-1970 macroeconomics useless. Indeed, Williamson (2011), for example, makes headway in analysing the financial crisis and monetary policy in the context of the crisis, in a way that conforms to the post-1970 macroeconomic research program.

Quiggin finds fault with New Keynesians, but wants to go in another direction (pp.128-29):

If there is one thing that distinguished Keynes's economic analysis from that of his predecessors, it was his rejection of the idea of a unique full employment equilibrium to which a market economy will automatically return when it experiences a shock. Keynes argued that an economy could shift from a full-employment equilibrium to a persistent slump as the result of the interaction between objective macroeconomic variables and the subjective 'animal spirits' of investors and other decisionmakers. It is this perspective that has been lost in the absorption of New Keynesian macro into the DSGE framework.

It is indeed true that New Keynesian models, which build on a basic real business-cycle framework, typically do not have 'persistent slumps'. A New Keynesian model focuses on the sub-optimality that comes from the relative price distortions arising from price and wage stickiness. However, there is a large and successful research program that deals with exactly the mechanism that Quiggin describes. The multiple equilibrium coordination-failure models of Bryant (1983), Diamond (1982), Cooper and John (1988), and the quantitative sunspot-equilibrium model of Farmer and Guo (1994), for example, either exhibit multiple steady states, or multiple equilibria driven by extrinsic uncertainty of the kind studied by Cass and Shell (1983) and Azariadis (1981). In the case of Diamond (1982), there are multiple Pareto-ranked steady states; for example, there can be a steady state with a high level of aggregate economic activity that Pareto-dominates a steady state with a low level of aggregate economic activity.

Further, the coordination-failure literature fits firmly in the post-1970 macroeconomic research program. Typically all of the economic agents in those models optimise, there is a well-defined equilibrium concept, and all of the behaviour is fully specified in terms that economic theorists would recognize. As well, those models do not provoke the unanswered questions that pop into our heads when we confront New Keynesian models. What economic forces would make a producer want to fix his or her price in nominal terms for extended periods of time? Why is a producer with a fixed price willing to accommodate all of the demand that arises for his or her good at that price? Why will would-be buyers and sellers in the labour market forgo Pareto-improving exchange? In the model in Diamond (1982), for example, we do not have to ask 
those questions. A Pareto improvement is possible, but to achieve that Pareto improvement requires collective action, which the specified environment does not permit.

Keynesians essentially dropped coordination-failure models in the mid-1990s in order to pursue the New Keynesian program. But that does not give Quiggin licence to ignore the coordination-failure literature. The spirit of that literature lives on, for example, in recent work by Roger Farmer (Farmer 2011), and the models are there to use.

Finally, Quiggin would in general like macroeconomists to think outside the box. The box he seems to have in mind is the competitive paradigm, but there has actually been plenty of broad exploration outside of those particular confines. For example, macroeconomists interested in labour market issues have long been attracted to models of search and matching, including the work for which Peter Diamond, Dale Mortensen and Christopher Pissarides received the Nobel Prize in economics. As well, Monetary economists use developments from the information economics literature and mechanism design, and macroeconomists who study credit markets and debt take an interest in models of limited commitment with strategic behaviour. Though Quiggin claims he would like to see more work using developments from decision theory, much of that has in fact been done. For example, Epstein and Zin (1989) applied non-expected utility preferences to asset pricing, in well-received work, and Krusell, Kurusku, and Smith (2010) study tax policy in the context of self-control.

Quiggin would like to see other broad exploration; for example, models that capture the ideas in Akerlof and Shiller (2009) or more applications of behavioural economics in macroeconomic modelling. My impression is that many macroeconomists are not so inclined to pick up the ball in those respects, though behavioural economics seems to have become popular in the field of finance. For many economists, I think Akerlof and Shiller's work crosses the boundary into weird economics, and behavioural economics may be seen as leading us down a slippery slope. At the bottom of that slippery slope, we conclude that everyone is stupid - individual consumers, firms, and policymakers - and we stupid economists should just close up shop and go home. For an interesting take on the state of behavioural economics, a good read is Levine (2011).

Of course, given an optimal state of affairs in economic research, we should observe economists pursuing a diverse set of ideas and research programs. Ideas that seem weird today may be the path-breaking ideas of tomorrow. However, in this chapter Quiggin fails to make the case that macroeconomic thought is infused with sub-optimality and in need of his visible correcting hand. 


\section{Trickle-down Economics}

What does Quiggin mean by 'trickle-down economics?' In his introduction (p.2) he states that this is: '...the idea that policies that benefit the well-off will ultimately help everybody'.

But in this chapter he also states (pp.146-47): 'The self-evident and weak version of the trickle-down theory starts from the observation that we all benefit, in all kinds of ways, from living in an advanced industrial society, with access to modern medical care, consumer goods, the Internet, and so on.'

We could also state this as 'a rising tide lifts all boats', which most of us have also heard before.

According to Quiggin, there existed a golden age of social democracy when things were more egalitarian, but since then there has been backsliding, driven by bad economic ideas, and we need to find ways to get back to the golden age. To evaluate that claim, it will be useful to review what economists have learned about the causes and consequences of economic growth, the differences in income and welfare across countries, and explanations for recent changes in the income distribution.

Hsieh and Klenow (2010) provide a nice summary of how received economic research views the determinants of income differences across countries. According to them, about 10-30 per cent of the differences are accounted for by human capital, about 20 per cent by physical capital, and the bulk - about 50-70 per cent - by total factor productivity (TFP). Thus, countries that are rich tend to be those with high TFP, which makes it clear what motivates people to move from, say, Malawi to the United States. Even if I am low-skilled - that is, I have accumulated a small quantity of individual-specific human capital my market wage will be much higher in the high-TFP US economy than in the low-TFP Malawi economy, and I will be much better off as a result. Further in the high-physical-and-human-capital and high-TFP US economy, because the opportunity cost of providing public goods - law enforcement, fire protection, roads, bridges, parks, healthcare - is lower, more of those public goods are provided, per capita, than is the case in Malawi. This provides all the more inducement to migrate.

Thus, in line with Quiggin's 'weak' statement above, some basic economics makes it clear that a rising tide raises all boats, and that things are trickling down, or perhaps flowing in a gushing torrent. But there is also a clear set of facts, particularly for the United States, pointing to an increase in the dispersion 
in income across the population in recent history. For example, wage data show an increase in wage dispersion, and in the skill premium, beginning perhaps about 1970 and increasing more dramatically from 1980 on.

Part of Quiggin's case seems to be that 'market liberalism' was responsible for much of the increase in income dispersion in the United States. Certainly changes in the structure of US income taxation and in trade barriers could be considered elements of market liberalism, but a good portion of the increase in income dispersion is accounted for by technological and structural change. Quiggin claims not, however (p.171): 'The term technology is often used to describe these changes, but this is just a catch-all residual term. There has been little if any evidence linking the growth in inequality to any particular technological innovation.'

It is hard to know how 'particular' Quiggin wants to get, though one gets the idea that he would never be satisfied. However, a substantial volume of excellent work in macroeconomics has been addressed to understanding the role of technical change in explaining the rise in the skill premium in the United States. Krusell et al. (2000), for example, is an important contribution.

What if, in fact, we think there is some sub-optimality related to the distribution of income in the United States? How could we quantify the effect of the income distribution on aggregate economic welfare? What would be the consequences of trying to make things more egalitarian, through various means? Is it possible that we would do more harm than good by attempting a move to greater egalitarianism? Unfortunately, Quiggin does not give us much in the way of sound economics to help us address these questions. Fortunately, however, some other excellent economists have given us a lot to go on.

Recent work by Jones and Klenow (2011) develops, using some standard economic theory, a measure of aggregate economic welfare that represents an alternative to our standard measure - real GDP per capita. The Jones-Klenow aggregate welfare measure takes account of consumption, leisure, inequality, and mortality. As our intuition might tell us, this measure, for example, shrinks the differences between Western Europe and the United States that we would see if we only looked at real GDP per capita. Americans consume more, but take less leisure, have higher inequality, and tend to live shorter lives than do Western Europeans.

A key question then would be whether, if the United States could make itself look more like Western Europe in inequality terms, it would look just like Western Europe in terms of the Jones-Klenow aggregate welfare measure, or 
whether in fact it could do much better according to the measure than it does now. Apparently Quiggin thinks that most economists would predict the former, while he would predict the latter.

What does Quiggin propose as effective tools for reducing inequality? One suggestion of his is to make taxes more progressive. However, as economists are well aware, increased progressivity comes at a cost. There is no doubt that an increase in the progressivity of the tax system has a negative effect on aggregate economic welfare by way of incentives.

Progressive taxation affects incentives through three key means: labour supply at the intensive margin; labour supply at the extensive margin; and human capital accumulation. Labour economists typically think of the intensive margin effect as small; workers at various income levels do not vary their hours of work much in response to after-tax wage rates, so higher marginal tax rates will have little effect. The extensive margin effect is another matter. Workers may choose to stay out of the labour force, retire early, or begin a career later in response to higher marginal tax rates, and those effects could be significant. For example, Prescott (2004) argues that higher marginal tax rates in some European countries are the key explanation for why Americans work so much more in total than in do the residents of those European countries. Prescott may be using a labour supply elasticity that is on the high side of consensus, but the effect he studies may nevertheless be quantitatively important.

In any event, the key effect of greater progressivity may come from changes in human capital accumulation - effects that we will see only over a long period of time. There is some evidence in support of this idea, in the work by Manuelli, Seshadri, and Shin (2011), for example. Thus, while it could be the case that an engineer may not vary his hours of work much, nor retire early if he or she faces a higher marginal income tax rate, those contemplating a career in engineering and facing a more progressive tax system might choose to take the easier and quicker route and opt for a career in plumbing instead. In the aggregate, this effect lowers the average level of skills in the economy, and not only makes the rich poorer, but reduces the tax base that is the source of revenue to give to the poor.

A second tool Quiggin would like to see used to promote equality is the promotion of union membership. Likely Quiggin thinks - and he would be correct - that most economists have the opinion that unions perform no useful economic role in modern society. While one could argue that unions played a crucial early role in the adoption of humane work practices and workplace safety, in most developed economies there is a well-established structure of laws and enforcement that deals effectively with safety on the job, workplace 
harassment, and other issues. A good case can be made that unions act mainly to stifle competition, to inhibit innovation, and to slow technological advance (see Holmes and Schmitz (2010), for example).

\section{Two nations}

That said, one can construct a sound economic rationale in support of the idea that there are key problems that we can successfully address, related to the distribution of income and wealth, particularly in the United States. The US economy can actually be characterised as consisting of two segmented economies - a rich economy and a poor one. In the rich economy, the average person is Caucasian, has acquired a large quantity of human capital, and is very well off, with access to a wide array of consumer goods and services, and also with access to some very sophisticated financial services. In the poor economy, the average person is African American or Hispanic, and has acquired a small quantity of human capital. This person also potentially has access to some of the same consumer goods and services as do the rich people, but access to the sophisticated financial services is much more difficult in the poor economy than in the rich one. Indeed, in the United States, a significant fraction of the population is 'unbanked'; that is, has no relationship with conventional financial intermediaries.

Are there policies governments can enact that will, possibly at little or no cost to the rich economy, make the poor economy look more like the rich one, perhaps by starting up a self-propelling engine of growth in the poor economy? of course, this is the same question we ask concerning less-developed countries. What can we do to make Malawi look more like the United States? However, the problem of making the poor-economy US look more like the rich-economy US may in fact be much more tractable. If we think of income differences between the rich and the poor in the US as arising from differences in TFP, in physical capital, and in human capital, surely those differences are accounted for much differently than when we account for development differences across countries.

In particular we should expect that TFP differences between the rich US and poor US would not account for much of the income differences, except to the extent that financial effects are reflected in TFP. Physical capital must account for something, but our conjecture is that the key explanation for US income dispersion is a human-capital gap. But how could this human-capital gap be narrowed? Quiggin thinks that there are problems in the United States with access to elite higher education. However, work by Heckman (2011), for example, suggests that the most efficient way to narrow the human-capital gap is not by sending more poor people to Harvard, but by investing more public resources in early-childhood education. 
Further, ideas related to the income distribution in the United States and the recent financial crisis that run counter to Quiggin's are those of Rajan (2010), for example. Rajan argues that concern with an increase in the dispersion in income in the United States led to passage of the Community Reinvestment Act, to huge growth in FNMA (Fannie Mae) and FHLMC (Freddie Mac) - governmentsponsored enterprises (GSEs) specialising in mortgage-market financial products - and to an expansion of the activities of the GSEs into activity targeted at low-income mortgage borrowers. These developments in turn, as Rajan argues, contributed directly to the financial crisis.

An alternative hypothesis comes from Acemoglu (2011), who argues that what has been going on at the very top of the US income distribution is critical to understanding the financial crisis. Acemoglu claims that a large increase in wealth in the financial sector was used by the participants in this sector to lobby the federal government for legislative action, and to put pressure on regulators. As a result, innovative financial institutions found themselves in an environment where they could take on large amounts of risk, hide the fact that they were doing so, reap the benefits in good times, and then appeal to the government's too-big-to-fail instincts to make out like bandits in bad states of the world.

Though Acemoglu seems to think that his ideas and Rajan's are mutually exclusive, it seems there are elements of truth in both. For example, Fannie Mae and Freddie Mac, which Acemoglu seems to want to absolve, were indeed part of the phenomenon he addresses. These are very large financial institutions which lobbied the federal government intensively so as to retain the advantages that had been carved out for them by the federal government through implicit guarantees, tax advantages, and so on. The too-big-to-fail problem associated with large commercial banks, investment banks, and insurance companies was also a problem for Fannie Mae and Freddie Mac, which have been under government conservatorship since September 2008 and receiving a steady and large flow of federal government bailouts. The GSEs, in their former life, could not only appeal to the instincts of legislators for less regulation, but to their instincts to help the middle class and the poor, giving them a very large base of support.

A key area of neglect in this chapter in Quiggin's book is the consideration of how some standard economics can be used to address resource-allocation and income-distribution issues associated with the financial crisis. A book review by Robert Solow (Solow 2010) highlights some of the issues nicely. Basic economics, from the time of Adam Smith, tells us that unfettered markets, with selfmotivated participants, can act to channel available resources to their best uses, and it is this set of ideas that motivated what Quiggin calls 'market liberalism'. Economists also know that things can go wrong with unfettered markets. One of 
the things that can go wrong is theft. Thieves are indeed self-motivated market participants who are exploiting profit opportunities. However, theft is a pure social loss. The time and effort of thieves is a direct waste, as this time and effort merely transfers goods and services from one person to another, and could be better allocated to productive uses. Further, there is indirect loss, as theft diminishes the profit that can be gained from socially useful economic activity, thus giving us less of it.

What do economists know about theft? Standard economics has been used by economists to explain criminal activity and to evaluate solutions to the social waste problem, at least since the early work of Becker (see Becker 1968, and Becker and Landes 1974). In analysing the financial industry in particular, we would like to know what financial activities are socially useful, and which activities are essentially theft, and how this socially wasteful theft may have contributed to what we know as the Global Financial Crisis. Now, when Ben Bernanke in 2004 spoke of 'the increased depth and sophistication of financial markets', clearly he was not thinking about theft, social waste, and the creation of financial instability. He had in mind the depth and sophistication of financial intermediaries in channelling savings efficiently from ultimate borrowers to ultimate lenders, and in shifting the burden of aggregate risks to those most capable of bearing them. But Bernie Madoff was a thief. Large financial institutions that took on excessive aggregate risk and received bailouts at taxpayer expense were also thieves, and their activity acted to concentrate aggregate risk and make the financial system less stable rather than more so.

If we want to analyse the financial crisis, isolate the problems, and propose solutions, applying ideas from the economics of crime will surely help, as this focuses attention on the right set of issues. How do we eliminate waste - theft - while retaining the elements of the financial system that actually produce social value-added? Transparency in financial arrangements is like providing outdoor lighting - it is harder to commit crimes in public view. We need to write appropriate regulations into law and make sure they are enforced. One thing is certain though: the Quiggin solutions of more progressivity in the tax system and more union membership are non-solutions which do not address the problems at hand. If the problem is theft by financial institutions and individuals, it is not efficient to solve the problem by taxing all rich people, only some of whom are thieves, nor is it helpful to unionise the cafeteria workers at Goldman Sachs.

\section{Which economists are the bad guys?}

Now, Quiggin's case in part involves an indictment of a particular group of economists who he associates with the five zombie ideas. This group of 
economists is apparently complicit in the conspiracy to make the rich richer by robbing the poor. However, in this respect it seems hard to square Quiggin's narrative with the facts. For example, Lawrence Summers is considered by many as an instrument of the financial community, as he played a key role in the late 1990s in blocking the regulation of the over-the-counter derivatives market. Such derivatives trading was an important contributor to the financial crisis. But Summers is also a famous critic of modern macroeconomics (see, for example, Summers 1986), which Quiggin also detests. Further, he appears to be sympathetic to Old Keynesianism, as is Quiggin. So does Quiggin think Summers is a good guy or a bad guy?

Here is another example. A key early contribution to the literature on the moral hazard problem in banking was Kareken and Wallace (1978), which showed how deposit insurance leads to excessive risk-taking. This idea can be extended in a straightforward way to address too-big-to-fail, which is essentially the same problem. When Kareken and Wallace wrote the book, both were affiliated with the Minneapolis Federal Reserve Bank. In 2004, then-President of the Minneapolis Fed Gary Stern, and Ron Feldman, Senior Vice President of the Minneapolis Fed, published Feldman and Stern (2004), which warned of the potential dangers of the too-big-to-fail doctrine and bank bailouts, well in advance of the financial crisis. Now, the Minneapolis Fed also provided research support for some of the key developments in modern macroeconomics. An early draft of Lucas (1976) was famously left behind at the Minneapolis Fed, ${ }^{4}$ and Thomas Sargent, Edward Prescott, and Neil Wallace, among others, who contributed crucial elements to the post-1970 research program in modern macro, were (and, in some cases, are still) on the payroll of the Minneapolis Fed. It seems Quiggin should be sympathetic to the idea that too-big-to-fail is a key source of financial instability and plays a role in making the rich richer, but again he detests modern macroeconomics. So is the Minneapolis Fed a good-guy institution or a bad-guy institution?

A broader point here is that, to the extent that individual economists influence politicians in Washington D.C., the Ivy League, or Ivy-League-educated, interventionist economists, rather than the Midwestern laissez-faire economists, have the bigger voice. Democratic administrations tend to bring on board academics such as Lawrence Summers and Christina Romer, and some of the conservative economists hired by Republican administrations, including Gregory Mankiw and John Taylor, are actually Keynesians when it comes to macro policies.

4 According to Tom Sargent. 


\section{Privatization}

This final chapter of Zombie Economics represents the closest thing to normal economics in Quiggin's book. Indeed, his discussion of the standard role of market failures in the determination of what the government should do and what it should not would fit well in any introductory undergraduate economics textbook. Arrow-Debreu, externalities, information economics, and monopoly power, for example, are discussed in a fairly conventional way.

The question which one should ask here is: if normal economics is so useful in telling us what the government should own (what it should not own and, more generally, what the government should take on), why can we not use normal economics to address macroeconomic questions? Presumably any role for the government in smoothing business cycles, for example, should be motivated by the existence of some market failure or failures, just as we would motivate government intervention in other respects by the existence of market failures. That is a basic principle of post-1970 macroeconomics - that is, that macroeconomic ideas should be subject to the same rigorous scrutiny as ideas in any other branch of economics.

While most economists would agree with Quiggin's general outline of how we should think about the role of government activity, he (taking the same kind of approach as elsewhere in his book) misrepresents a very extreme view as mainstream. He states (p.186):

When all the spurious arguments for privatization are stripped away, the central tenet of the ideology of privatization is simple. It is the claim that an economy in which all major decisions on investment, employment, and production are left to private firms will outperform a mixed economy where governments play a significant role in such decisions. Provided private firms are free to compete on a 'level playing field,' this means they will always have a higher value than they would under public ownership.

There must be an economist whose ideas match what is written in that paragraph, but the identity of that person appears to be a well-kept secret. Not even Milton Friedman thought that the government should play no 'significant role' in the economy. 


\section{Conclusion}

The target audiences for this book appear to be those interested in the financial crisis (almost everyone), lay people with perhaps some specific economic knowledge, and economists in general. People tend to enjoy stories about incompetence and conspiracies, and in those respects Zombie Economics has the ingredients for success. But, as economists, we are looking for something more. First, we would like such a book to represent the economics profession well to lay people. We do not need to be depicted as angels, but the book should be honest. Second, since the book deals explicitly with the financial crisis, we would like it to use relevant economics to make sense of the crisis and construct well-thought-out solutions to the problems the crisis highlights. Third, the book should provide useful guidance for economic researchers.

Unfortunately, Quiggin's urge to construct a simple narrative, and his political goals, get in the way of sound economics. Quiggin would have us believe that financial economists, macroeconomists, and various other economists enamoured with the theoretical beauty of well-functioning markets, have constructed tools which, if we use them, will lead us astray. In particular, the poor will suffer, and society will be worse off as a result.

Nothing could be further from the truth. The tools of modern finance and macroeconomics are not the instruments of conservative elements in society, serving only to bludgeon the working class. These in fact are the tools of science, and as such they can be used effectively by liberals and conservatives alike to make the world a better place. Misrepresenting the tools of science as the products of some vast conspiracy is as anti-intellectual an activity as the promotion of 'intelligent design' as science, or the dismissal of informed scientific views on climate change.

\section{References}

Acemoglu, D. 2011, 'Thoughts on Inequality and the Financial Crisis,' http:// econ-www.mit.edu/files/6348

Akerlof, G. and Shiller, R. 2009, Animal Spirits: How Human Psychology Drives the Economy and Why It Matters for Global Capitalism, Princeton University Press, Princeton NJ.

Azariadis, C. 1981, 'Self-Fulfilling Prophesies', Journal of Economic Theory 25: 380-96. 
Becker, G. 1968, 'Crime and Punishment: An Economic Approach', Journal of Political Economy 76: 196-217.

Becker, G. and Landes, W. (eds) 1974, Essays in the Economics of Crime and Punishment, National Bureau of Economic Research, Cambridge MA.

Bernanke, B. 2004, Remarks by Governor Ben S. Bernanke at the meetings of the Eastern Economic Association, Washington, DC, 20 February 2004: The Great Moderation, http://www.federalreserve.gov/boarddocs/ speeches/2004/20040220/default.htm

Black, F. and Scholes, M. 1973, 'The Pricing of Options and Corporate Liabilities', Journal of Political Economy 81: 637-54.

Bryant, J. 1983, 'A Simple Rational Expectations Keynes-Type Model,' Quarterly Journal of Economics 98: 525-28.

Cass, D. and Shell, K. 1983, 'Do Sunspots Matter?' Journal of Political Economy 91: 193-227.

Chari, V. V. and Kehoe, P. 1990, 'Sustainable Plans', Journal of Political Economy 98: 783-802.

Clarida, R., Gali, J. and Gertler, M. 1999, 'The Science of Monetary Policy: A New Keynesian Perspective', Journal of Economic Literature 37: 1661-707.

Cooper, R. and John, A. 1988, 'Coordinating Coordination Failures in Keynesian Models', Quarterly Journal of Economics 103: 441-63.

Diamond, D. and Dybvig, P. 1983, 'Bank Runs, Deposit Insurance, and Liquidity', Journal of Political Economy 91: 401-19.

Diamond, P. 1982, 'Aggregate Demand Management in Search Equilibrium', Journal of Political Economy 90: 881-94.

Ennis, H. and Keister, T. 2010, 'Banking Panics and Policy Responses', Journal of Monetary Economics 57: 404-19.

Epstein, L. and Zin, S. 1989, 'Substitution, Risk Aversion, and the Temporal Behavior of Consumption and Asset Returns: A Theoretical Framework', Econometrica 57: 937-69.

Farmer, R. 2011, 'Animal Spirits, Rational Bubbles and Unemployment in an Old Keynesian Model', working paper, UCLA and NBER.

Farmer, R. and Guo, J. 1994, 'Real Business Cycles and the Animal Spirits Hypothesis', Journal of Economic Theory 63: 42-72. 
Feldman, R. and Stern, G. 2004, Too Big to Fail: The Hazards of Bank Bailouts, Brookings Institution Press, Washington D.C.

Friedman, M. 1960, A Program for Monetary Stability, Fordham University Press, New York.

Gorton, G. 2010, 'Questions and Answers About the Financial Crisis - Prepared for the U.S. Financial Crisis Inquiry Commission,' manuscript, Yale School of Management and NBER.

Gorton, G. and Metrick, A. 2010, 'Regulating the Shadow Banking System', working paper, Yale School of Management and NBER.

Holmes, T. and Schmitz, J. 2010, 'Competition and Productivity: A Review of Evidence', Annual Review of Economics 2: 619-42.

Heckman, J. 2011, 'The Economics of Inequality: The Value of Early Childhood Education', American Educator 35: 31-35.

Hsieh, C. and Klenow, P. 2010. 'Development Accounting,' American Economic Journal: Macroeconomics 2, 207-223.

Jones, C. and Klenow, P. 2011, 'Beyond GDP? Welfare Across Countries and Time', working paper, Stanford University.

Kareken, J. and Wallace, N. 1978, 'Deposit Insurance and Bank Regulation: A Partial-Equilibrium Exposition', Journal of Business 51: 413-38.

Kelly, K. 1999, New Rules for the New Economy: Ten Radical Strategies for a Connected World, Penguin.

Krugman, P. 2009, 'How Did Economists Get It So Wrong?' New York Times Magazine, September 2.

2011, 'The Profession and the Crisis', Eastern Economic Journal 37: 30712.

Krusell, P., Kurusku, B., and Smith, A. 2010, 'Temptation and Taxation', Econometrica 78: 2063-84.

Krusell, P., Ohanian, L., Rios-Rull, J., Violante, G. 2000, 'Capital-Skill Complementarity and Inequality: A Macroeconomic Analysis', Econometrica 68: 1029-53.

Kydland, F. and Prescott, E. 1977, ‘Rules Rather Than Discretion: The Inconsistency of Optimal Plans', Journal of Political Economy 85: 473-92. 
Agenda, Volume 18, Number 3, 2011

Kydland, F. and Prescott, E. 1982, 'Time to Build and Aggregate Fluctuations', Econometrica 50: 1345-70.

Levine, D. 2011, 'Is Behavioral Economics Doomed?' http://www.dklevine.com/ general/behavioral/doomed.htm

Lucas, R. 1972, 'Expectations and the Neutrality of Money', Journal of Economic Theory 4: 103-24.

1976, 'Econometric Policy Evaluation: A Critique', Carnegie-Rochester Conference Series on Public Policy 1(1): 19-46.

1978, 'Asset Prices in an Exchange Economy', Econometrica 46: 1429-45.

Manuelli, R., Seshadri, A., and Shin, Y. 2011, 'Lifetime Labor Supply and Human Capital Investment', working paper, Washington University and University of Wisconsin-Madison.

Phelps, E. (ed.) 1970, The Microeconomic Foundations of Employment and Inflation Theory, Norton.

Prescott, E. 1986, 'Theory Ahead of Business Cycle Measurement', Federal Reserve Bank of Minneapolis Quarterly Review 10(4).

2004, 'Why Do Americans Work So Much More Than Europeans?' Federal Reserve Bank of Minneapolis Quarterly Review 28: 2-13.

Quiggin, J. 2010, Zombie Economics: How Dead Ideas Still Walk Among Us, Princeton University Press, Princeton NJ.

Rajan, R. 2010, Fault Lines: How Hidden Fractures Still Threaten the World Economy, Princeton University Press, Princeton NJ.

Samuelson, P. and Solow, R. 1960, 'Analytical Aspects of Anti-Inflation Policy', American Economic Review Papers and Proceedings 50: 177-94.

Sargent, T. and Wallace, N. 1982, 'The Real-Bills Doctrine versus the Quantity Theory: A Reconsideration', Journal of Political Economy 90: 1212-36.

Solow, R. 2010, 'Hedging America', The New Republic, January 12, http://www. tnr.com/article/books-and-arts/hedging-america?page $=0,0$.

Stock, J. and Watson, M. 2002, 'Has the Business Cycle Changed and Why?' in Gertler, M. and Rogoff, K. (eds), NBER Macroeconomics Annual 2002, MIT Press, Cambridge, MA.

Summers, L. 1986, 'Some Skeptical Observations on Real Business Cycle Theory', Federal Reserve Bank of Minneapolis Quarterly Review, Fall. 
Williamson, S. 2011, 'Liquidity, Monetary Policy, and the Financial Crisis: A New Monetarist Approach', working paper, Washington University in St. Louis.

Williamson, S. and Wright, R. 2010, 'New Monetarist Economics: Methods', Federal Reserve Bank of St. Louis Review 92: 265-302.

2011, 'New Monetarist Economics: Models' in Benjamin Friedman and Michael Woodford (eds), Handbook of Monetary Economics, vol. 3A.

Woodford, M. 2003, Interest and Prices: Foundations of a Theory of Monetary Policy, Princeton University Press, Princeton NJ. 